\title{
The Role of Women in Pest Management Decision Making in Eastern Uganda ${ }^{1}$
}

\author{
Dr. J. Mark Erbaugh, Assistant Director \\ International Programs in Agriculture \\ The Ohio State University \\ 113 Agricultural Administration Building, 2120 Fyffe Road \\ Columbus, Ohio, 43210 \\ E-mail: erbaugh1@osu.edu \\ Dr. Joseph Donnermeyer, Professor \\ Department of Human and Community Resource Development \\ The Ohio State University \\ 250 Agricultural Administration Building, 2120 Fyffe Road \\ Columbus, Ohio 43210 \\ E-mail: donnermeyer.1@osu.edu \\ Ms. Magdalene Amujal \\ Department of Agricultural Extension and Education \\ Makerere University \\ P.O. Box 7062 \\ Kampala, Uganda \\ Dr. Samuel Kyamanywa, Associate Professor \\ Department of Crop Science \\ Makerere University \\ P.O. Box 7062 \\ Kampala, Uganda \\ E-mail: kyamanywa@infocom.co.ug
}

\begin{abstract}
Gender can influence knowledge acquisition and on-farm decision making and must be thoroughly understood if agricultural research and extension programs are to design appropriate technologies for small-scale farming systems. In order to improve IPM program design and delivery, two hundred farmers (52\% women, 48\% men) from Eastern Uganda were surveyed in 1999, to explore perceptual and knowledge differences between men and women about crop production and pest management. The results indicate that women do play an important role in agricultural production and pest management; however, there is no indication that women play a predominant role in either. Pest management decisions appear to be made by the household head, whether that person is a male or female. Women have greater knowledge of dimensional attributes of IPM than men, particularly awareness of potential harmful effects of synthetic pesticides. Thus targeting women may expedite adoption of IPM.
\end{abstract}

Keywords: Gender, Women, Pest Management, Data-Differentiation, Uganda, Decision-Making

1 Acknowledgments: This research was supported by IPM CRSP, which is funded by the U.S. Agency for International Development (USAID) under Agreement No. LAG-4196-G-00-5001-00 to Virginia Tech University. Additional support was provided by the International Programs in Agriculture Office at The Ohio State University. 


\section{Introduction}

Women's sizeable and increasing contribution to food crop production in SubSaharan Africa has been well documented (Blumberg, 1992; Synder, 1990; Saito et al., 1994). Equally well documented is that women have often been overlooked or excluded from many agricultural development efforts. As a consequence, women frequently lack access to new information, production methods and support services, and this has led to both project failures and inequitable and unsustainable development. It is now recognized that increasing women's participation in agricultural development efforts is essential if agricultural output and productivity is to be improved in Sub-Saharan Africa (Saito et al., 1994).

Newer approaches to agricultural research and development advocate specifically targeting disadvantaged groups such as women to ensure their participation in the process of agricultural technology design and delivery. The IPM CRSP has been implementing a participatory IPM approach with small-scale farmers in Eastern Uganda since 1995. The main objective of this program has been to work with farmers in developing pest management alternatives to sole reliance on synthetic pesticides. From the beginning, this project accessed and assessed women's knowledge and role in pest management to ensure that their interests and knowledge were not overlooked and were incorporated into the research and extension process.

\section{Theoretical Framework}

Gender often influences knowledge acquisition and on-farm decision making and these differences must be thoroughly understood if agricultural research and extension programs are to design appropriate technologies for smallscale farming systems. Gender based knowledge differentials occur because men and women have different roles and responsibilities and perform different agricultural activities. Failure to assess these knowledge differences can impact technology design and impede adoption (Staudt, 1987).

\section{Purpose}

It has been asserted that women are the main agents of pest management in African agriculture and that this has important implications for the generation and implementation of IPM programs (Malena, 1994). One of the key assumptions of the IPM CRSP program in Uganda has been that women's knowledge of and role in pest management may differ from men. The purpose of this study is to explore perceptual and knowledge differences between men and women of crop production and pest management in Eastern Uganda, and to use this information to improve IPM program design and delivery. Specifically, the study assesses genderdifferentiated access to resources, decisionmaking, division-of-labor, perceptions of pest and disease problems and current roles in pest management.

\section{Methods/Data Source}

The research design for this study employed a descriptive survey method. A multistage sampling procedure was used to select eight villages in two districts in Eastern Uganda. In each district, 4 sub-counties were selected, with two of these being sub-counties where the IPM CRSP had active programs and two others where the CRSP had not previously been active. The selection of sub-counties where the IPM CRSP had not been active was based on geographical proximity and agro-ecological similarity to those where the IPM CRSP had been active. Villages in each sub-county were then purposively selected: two were selected near NGOs that had worked with the IPM CRSP. In sub-counties where the IPM CRSP had not been active, villages were selected near an identified, active farmer NGO. Lists of farmers for each village were obtained from local council officials at the village level. A systematic random sample of 25 farmers was selected from each village, totaling 100 interviews in each district, and 200 interviews in all.

Enumerators were selected based on their familiarity with local languages, survey methodology and past experience with IPM CRSP activities. Two female enumerators from each district were selected to avoid response bias, cultural sensitivities that might preclude women being interviewed by male enumerators, and to ensure women's participation. Female 
enumerators were instructed to interview female farmers knowledgeable of the farm operation when possible. Enumerators, both male and female, were instructed to follow the systematic selection process described above. All questionnaires were completed by personal interviews during the second half of the first growing season (June through early July), 1999.

\section{Findings}

Characteristics of respondents: Of the survey respondents, $52 \%$ were female and $48 \%$ were male. One reason that the number of female respondents was greater than male respondents was that "head-of-household" was not used as an interview-screening question. Many have noted that using "head-ofhousehold" as a screening question often eliminates female respondents, who may not be head of the household but who are nevertheless knowledgeable of and important contributors to on-farm production (Tefft et al., 1991; Malena, 1994). The results provide support for this approach. Out of the 104 female respondents, $40 \%$ reported being heads-of-households and the remaining $60 \%$ reported that even though they were not heads, that they were knowledgeable of the farm enterprise. De jure female heads comprised $74 \%$ of the female heads-ofhousehold, with the remaining $26 \%$ being de facto heads ${ }^{1}$.
There were no significant differences between male and female respondents on age, years of education, acres in production, and extension contacts (Table 1). Significant mean differences were reported for household size, use of part-time labor, and farm income. Female respondents reported larger average household sizes and the use of more part-time labor than male respondents; and male respondents reported larger farm incomes averaging between \$200-300 per year.

Division of Labor: Both men and women indicated that the most common form of dividing on-farm labor was by task, not by crop or separate fields (Table 2). However, division of labor by crop was associated with men in Iganga district (Table 3). Further analysis indicated that coffee, a primary cash crop in Iganga, was perceived to be a man's crop by both men and women. There were no significant differences between males and females about who performs the agricultural tasks of land clearing, planting, weeding and harvesting (Table 4). Land clearing was viewed by male and female farmers as either a male task or an activity performed by both males and females from the same household. Planting, weeding and harvesting were perceived largely as activities performed by both. The agreement by both men and women that both did weeding was an unexpected finding and may be an artifact of this study. The only significant gender-based difference in performance of agricultural tasks occurred for land cultivation. Men were more likely to perceive land cultivation as an activity done by both, whereas women perceived it as more of a male activity.

\footnotetext{
${ }^{1}$ Gladwin et al. (1997) define de jure femaleheaded households as those in which the head is divorced, widowed, or a single parent and must make all decisions and provide all support for the family. De facto female-headed households are those in which the husband is temporarily away, making it necessary for the wife to make at least some of the agricultural decisions, possibly aided by remittances from husband.
} 
Volume 10, Number 3

Table 1

Background Characteristics and Production Resources

\begin{tabular}{lcccc}
\hline Variable Name & Male & Female & & \\
\hline Age & $(N=96)$ & $(N=104)$ & $d f$ & $t$ \\
Years of Education & $40.32(13.71)$ & $39.89(11.12)$ & 198 & -.244 \\
Household Size & $6.91(3.39)$ & $6.76(3.16)$ & 198 & -.316 \\
Farm Income & $7.43(3.35)$ & $9.69(4.72)$ & 198 & $3.93^{* *}$ \\
Acres in Crops & $3.35(1.81)$ & $2.81(1.60)$ & 198 & $-2.26^{*}$ \\
Hired Labor & $5.95(5.43)$ & $5.44(4.41)$ & 198 & -.732 \\
Extension Visits & $1.78(1.43)$ & $2.45(1.94)$ & 198 & $2.79^{* *}$ \\
\hline
\end{tabular}

Note. Values in parentheses are standard deviations.

$* p<.05 ; * *<.01$

Table 2

Male/Female Perceptions of Division of Labor (DOL)

\begin{tabular}{cccccccc}
\hline Type of DOL & $\begin{array}{c}\text { Male } \\
(N=96)\end{array}$ & $\begin{array}{c}\text { Female } \\
(N=104)\end{array}$ & $\begin{array}{c}\text { Total } \\
(2000 \text { survey })\end{array}$ & $\begin{array}{c}\text { Total } \\
(1995 \text { survey })\end{array}$ & $\begin{array}{c}\text { Total } \\
(1993 \text { survey })\end{array}$ & $X^{2}$ & Phi \\
\hline DOL Task & & & & & & & \\
yes & 64 & 64 & $128(64)$ & $68(68)$ & $301(53)$ & .570 & .053 \\
no & 32 & 40 & $72(36)$ & $32(32)$ & $275(47)$ & & \\
DOL Crop & & & & & $151(26)$ & $4.9^{*}$ & $.157^{*}$ \\
yes & 37 & 25 & $62(31)$ & & $429(74)$ & & \\
no & 59 & 79 & $138(69)$ & & &
\end{tabular}

Note. Numbers in parentheses are column percentages; Degrees of Freedom $=1$.

$* p<.05$

Table 3

Male/Female Perceptions of Division of Labor (DOL) by District

\begin{tabular}{|c|c|c|c|c|c|}
\hline Type of DOL & Male $(N=51)$ & Female $(N=49)$ & Total & $X^{2}$ & Phi \\
\hline $\begin{array}{l}\text { Iganga Dist. } \\
\text { DOL by Task }\end{array}$ & & & 100 & & \\
\hline yes & 27 & 12 & 39 & $8.50 * *$ & $.29 * *$ \\
\hline no & 24 & 37 & 61 & & \\
\hline DOL by crop & & & 100 & & \\
\hline yes & 25 & 4 & 29 & $20.26 * *$ & $.45^{* *}$ \\
\hline no & 26 & 45 & 71 & & \\
\hline Kumi Dist. & Male $(N=45)$ & Female $(N=55)$ & 100 & & \\
\hline \multicolumn{6}{|l|}{ DOL by Task } \\
\hline yes & 37 & 52 & 89 & $3.84^{*}$ & $.20^{*}$ \\
\hline no & 8 & 3 & 11 & & \\
\hline \multicolumn{6}{|l|}{ DOL by crop } \\
\hline yes & 12 & 21 & 33 & 1.48 & .12 \\
\hline no & 33 & 34 & 67 & & \\
\hline
\end{tabular}

Note. Numbers in parentheses are column percentages; Degrees of Freedom $=1$.

$* p<.05 ; * * p<.01$ 
Table 4

Male/Female Perceptions of Division of Labor by Task

\begin{tabular}{|c|c|c|c|c|c|c|}
\hline TASK & $\begin{array}{c}\text { Male } \\
(N=96)\end{array}$ & $\begin{array}{c}\text { Female } \\
(N=104)\end{array}$ & Total & $X^{2}$ & Cramer's V & $\mathrm{Phi}^{\mathrm{a}, \mathrm{b}}$ \\
\hline \multicolumn{7}{|l|}{ Land Clearing } \\
\hline men & 51 & 53 & 104 & 4.23 & .145 & ${ }^{\mathrm{a}} .894$ \\
\hline women & 1 & 7 & 8 & & & \\
\hline both & 44 & 44 & 88 & & & \\
\hline \multicolumn{7}{|l|}{ Land Cultivation } \\
\hline men & 20 & 45 & 65 & $19.43 * *$ & $.312 * *$ & ${ }^{\mathrm{a}} .266^{* *}$ \\
\hline women & 0 & 6 & 6 & & & \\
\hline both & 76 & 53 & 129 & & & \\
\hline \multicolumn{7}{|l|}{ Planting } \\
\hline men & 3 & 2 & 5 & 2.24 & .106 & ${ }^{\mathrm{b}} .062$ \\
\hline women & 3 & 8 & 11 & & & \\
\hline both & 90 & 94 & 184 & & & \\
\hline \multicolumn{7}{|l|}{ Weeding } \\
\hline men & 2 & 0 & 2 & 4.09 & .143 & ${ }^{\mathrm{b}} .05$ \\
\hline women & 3 & 8 & 11 & & & \\
\hline both & 91 & 96 & 187 & & & \\
\hline \multicolumn{7}{|l|}{ Harvesting } \\
\hline men & 2 & 0 & 2 & 6.27 & $.177 *$ & ${ }^{\mathrm{b}} .084$ \\
\hline women & 1 & 7 & 8 & & & \\
\hline both & 93 & 97 & 190 & & & \\
\hline
\end{tabular}

Note. $X^{2}$ and Cramer's V, Degrees of Freedom = 2; Phi, Degrees of Freedom =1; Phi $^{\mathrm{a}}-$ Cell row counts for women less than minimum were collapsed into "both"; Phi ${ }^{\mathrm{b}}$ - Cell row counts for men/women less than minimum were collapsed.

$* p<.05 ; * * p<.01$

Agricultural Decision Making: There was an association between gender and perceptions of who makes household farming decisions (Table 5). Men indicated that they made the farming decisions or jointly with wives; whereas women indicated that they made the decisions or were made jointly with husbands. Men and women living with their spouses expressed this same association. Not surprisingly, when the perceptions of women only were examined we found that female de jure headed households were more likely to indicate that women made the decisions than were females who were not heads-ofhouseholds.
There was also a significant difference between gender and perceptions of who controls the income from farm production; however, this difference was not as pronounced as that for farming decisions. Men seem to indicate that they shared control of farm income with women whereas women believe they controlled farm income (Table 6). There was no difference in perceptions of who controls farm income among men and women with spouses. But, there were differences between female heads and nonheads: female-headed households were more likely to indicate that they controlled farm income. 


\section{Table 5}

Perceptions of who makes household farming decisions.

\begin{tabular}{|c|c|c|c|c|c|c|}
\hline $\operatorname{All}(N=200)$ & $\begin{array}{c}\text { Male } \\
(N=96)\end{array}$ & $\begin{array}{l}\text { Female } \\
(N=104)\end{array}$ & Total & $X^{2}$ & Cramer's V & $\mathrm{Phi}^{1}$ \\
\hline men & 39 & 9 & 48 & $43.46^{* *}$ & $.466^{* *}$ & \\
\hline women & 8 & 44 & 52 & & & \\
\hline both & 49 & 51 & 100 & & & \\
\hline $\begin{array}{l}\text { Only: male/female living } \\
\text { with spouse }\end{array}$ & $\begin{array}{c}\text { Male } \\
(N=87)\end{array}$ & $\begin{array}{l}\text { Female } \\
(N=73)\end{array}$ & & & & \\
\hline men & 34 & 9 & 43 & $19.76 * *$ & $.351^{* *}$ & \\
\hline women & 7 & 20 & 27 & & & \\
\hline both & 46 & 44 & 90 & & & \\
\hline $\begin{array}{l}\text { Women only: household heads } \\
\& \text { non heads }(N=104)\end{array}$ & $\begin{array}{l}\text { Heads } \\
(N=42)\end{array}$ & $\begin{array}{c}\text { Non Heads } \\
(N=62)\end{array}$ & & & & \\
\hline men & 0 & 9 & 9 & $26.23 * *$ & $.502 * *$ & $.485 * *$ \\
\hline women & 30 & 14 & 44 & & & \\
\hline both & 12 & 39 & 39 & & & \\
\hline
\end{tabular}

Note. $X^{2}$ and Cramer's V, Degrees of Freedom $=2$; Phi, Degrees of Freedom $=1$; ${ }^{1} \mathrm{Phi}-$ Cell row counts for men less than minimum were collapsed into both.

$* p<.05 ; * * p<.01$

Table 6

Perceptions of Who Controls Income From Farm Production

\begin{tabular}{cccccc}
\hline All $(N=200)$ & $\begin{array}{c}\text { Male } \\
(N=96)\end{array}$ & $\begin{array}{c}\text { Female } \\
(N=104)\end{array}$ & Total & $X^{2}$ & Cramer's V \\
\hline men & 23 & 27 & 50 & $11.89^{* *}$ & $.244^{* *}$ \\
women & 18 & 40 & 58 & & \\
both & 55 & 37 & 92 & & \\
Only: male/female living with spouse & Male & Female & & & \\
$(N=160)$ & $(N=87)$ & $(N=73)$ & & & \\
men & 18 & 20 & 38 & 4.09 & .160 \\
women & 17 & 21 & 38 & & \\
both & 52 & 32 & 84 & & \\
Women only: household heads \& & Heads & Non Heads & & & \\
non heads $(N=104)$ & $(N=42)$ & $(N=62)$ & & & $.314^{* *}$ \\
men & 11 & 16 & 27 & $10.30^{* *}$ & \\
women & 23 & 17 & 40 & & \\
both & 8 & 29 & 37 & & \\
\hline
\end{tabular}

Note. Degrees of Freedom $=2$.

$* p<.05 ; * * p<.01$ 
Pesticide Decision Making and Use:

There was not a relationship between gender and the use of pesticides (Table 7). In fact, use of pesticides was more related to the district than to gender, with both male and females in Kumi more likely to use pesticides than those in Iganga. However, men perceived pesticide decision making and purchases as largely male affairs, whereas women perceived pesticide decision making as a female or a household decision and pesticide purchases as either a male or female decision but generally not a shared decision (Tables $8 \& 9$ ).

These relationships were maintained for males and females living with spouses and female heads and non-heads of households. There was a general agreement between men and women that although women were as likely to indicate that they were having their fields sprayed with pesticides men were more likely to be doing the actual pesticide application (Table $10)$.

Table 7

Pesticide Use

\begin{tabular}{cccccc}
\hline All $(N=200)$ & Male $(N=96)$ & Female $(N=104)$ & Total & $X^{2}$ & phi \\
\hline Not Using & 37 & 37 & 74 & .188 & .031 \\
Using & 59 & 67 & 126 & & \\
By District & Iganga $(N=100)$ & Kumi $(N=100)$ & & & \\
Not Using & 56 & 18 & 74 & $30.97 * *$ & $.394^{* *}$ \\
Using & 44 & 82 & 126 & & \\
\hline
\end{tabular}

Note. Degrees of Freedom $=1$.

$* p<.05 ; * * p<.01$

Table 8

Person in the Household who makes Pesticide Use Decision (Pesticide Users Only)

\begin{tabular}{|c|c|c|c|c|c|c|}
\hline $\begin{array}{l}\text { Pesticide Users Only } \\
(N=126)\end{array}$ & $\begin{array}{c}\text { Male } \\
(N=59)\end{array}$ & $\begin{array}{l}\text { Female } \\
(N=67)\end{array}$ & Total & $X^{2}$ & Cramer's V & $\mathrm{Phi}^{1}$ \\
\hline men & 44 & 11 & 55 & $47.51 * *$ & $.614^{* *}$ & \\
\hline women & 3 & 32 & 35 & & & \\
\hline both & 12 & 24 & 36 & & & \\
\hline Only: male/female & Male & Female & & & & \\
\hline living with spouse $(N=98)$ & $(N=54)$ & $(N=44)$ & & & & \\
\hline men & 41 & 9 & 50 & $31.52 * *$ & .567 & \\
\hline women & 2 & 13 & 15 & & & \\
\hline both & 11 & 22 & 33 & & & \\
\hline $\begin{array}{l}\text { Women only: household } \\
\text { heads \& non heads }(N=67)\end{array}$ & $\begin{array}{l}\text { Heads } \\
(N=30)\end{array}$ & $\begin{array}{l}\text { Non Heads } \\
(N=37)\end{array}$ & & & & \\
\hline men & 2 & 9 & 11 & $26.65 * *$ & $.642 * *$ & $.641 * *$ \\
\hline women & 25 & 7 & 32 & & & \\
\hline both & 3 & 21 & 24 & & & \\
\hline
\end{tabular}

Note. $X^{2}$ and Cramer's V, Degrees of Freedom $=2$; Phi, Degrees of Freedom $=1 ;{ }^{1} \mathrm{Phi}-$ Cell row counts for men less than minimum were collapsed into "both".

$* p<.05 ; * * p<.01$ 
Table 9

Person in the Household who Purchases Pesticides (Pesticide Users Only)

\begin{tabular}{|c|c|c|c|c|c|c|}
\hline $\begin{array}{l}\text { Person Purchasing Pesticides } \\
(N=122)\end{array}$ & $\begin{array}{c}\text { Male } \\
(N=58)\end{array}$ & $\begin{array}{l}\text { Female } \\
(N=64)\end{array}$ & Total & $X^{2}$ & Cramer's V & $\mathrm{Phi}^{1}$ \\
\hline men & 57 & 35 & 92 & $31.49 * *$ & $.508 * *$ & $.505^{* *}$ \\
\hline women & 0 & 21 & 21 & & & \\
\hline both & 1 & 8 & 9 & & & \\
\hline $\begin{array}{l}\text { Only male/female living } \\
\text { with spouse }(N=97)\end{array}$ & $\begin{array}{c}\text { Male } \\
(N=54)\end{array}$ & $\begin{array}{l}\text { Female } \\
(N=43)\end{array}$ & & & & \\
\hline men & 53 & 29 & 82 & $17.57 * *$ & $.426 * *$ & $.422 * *$ \\
\hline women & 0 & 8 & 8 & & & \\
\hline both & 1 & 6 & 7 & & & \\
\hline $\begin{array}{l}\text { Women only: household } \\
\text { heads \& non heads }(N=64)\end{array}$ & $\begin{array}{l}\text { Heads } \\
(N=28)\end{array}$ & $\begin{array}{l}\text { Non Heads } \\
(N=36)\end{array}$ & & & & \\
\hline men & 10 & 25 & 35 & $13.40 * *$ & $.458 * *$ & $.336 * *$ \\
\hline women & 16 & 5 & 21 & & & \\
\hline both & 2 & 6 & 8 & & & \\
\hline
\end{tabular}

Note. $X^{2}$ and Cramer's V, Degrees of Freedom $=2$; Phi, Degrees of Freedom $=1$; ${ }^{1}$ Phi - Cell row counts for women less than minimum were collapsed into "both".

$* p<.05 ; * * p<.01$

Table 10

Person in the Household who Applies Pesticides (Pesticide Users Only)

Gender of Household

Pesticide Applicator Male Female

\begin{tabular}{ccccccc}
$(N=126)$ & $(N=59)$ & $(N=67)$ & Total & $X^{2}$ & Cramer's V & Phi $^{1}$ \\
\hline men & 56 & 54 & 110 & $6.26^{*}$ & $.244^{*}$ & $.201^{*}$ \\
women & 3 & 7 & 10 & & & \\
both & 0 & 6 & 6 & & &
\end{tabular}

Note. $X^{2}$ and Cramer's V, Degrees of Freedom $=2$; Phi, Degrees of Freedom $=1 ;{ }^{1}$ Phi - Cell row counts for women less than minimum were collapsed into "both".

$* p<.05 ; * * p<.01$

Women who said they were applying pesticides were living without a male in the household and tended to be older. The most important source for information on pesticide usage was extension agents. However, more women than men indicated that extension agents were their most important source of pesticide information. Men in Kumi were more likely to get their pesticide information from vendors at local markets. Men in both districts were more likely than women to obtain information from labels on the pesticide package. Finally, there was no significant difference between men and women on the number of pesticide applications per season and on their attitudes towards pesticides. Men applied pesticides about 6 times and women 5 times per season. Overall, both men and women had favorable attitudes about pesticides indicating they would like to use more of them. However, men had slightly more favorable attitudes about pesticides than women.

Knowledge of IPM: A summated ratings scale consisting of four attributes of IPM was devised to measure farmers' knowledge of IPM (Table 11). The coefficient of reliability for the knowledge of IPM scale was .72, indicating an acceptable level of reliability. Using a T-test to compare mean scores on the IPM knowledge scale indicated that on average, women were more knowledgeable of IPM than were men. Closer investigation of this knowledge difference indicates that women were significantly more knowledgeable about possible negatives effects from pesticide use, and had more knowledge of alternative pest control measures and beneficial insects, although these 
latter two variables were not significant.

Whereas men were more likely to state that pesticide costs were a negative, women were more likely to indicate that pesticide use could result in sicknesses and other health related effects from using pesticides.

Table 11

Mean Differences between Males and Females on Knowledge of IPM

\begin{tabular}{lrcrcccc}
\hline & \multicolumn{3}{c}{$\begin{array}{c}\text { Male } \\
\text { Variable Name }\end{array}$} & $\begin{array}{c}\text { Female } \\
(N=96)\end{array}$ & $\begin{array}{c}\text { Pearson's } \\
\text { Range }\end{array}$ & $\begin{array}{c}\text { Kendalls } \\
\text { tau-b }\end{array}$ \\
\hline IPM Scale & $0-10$ & $2.58(2.07)$ & $3.68(2.49)$ & 198 & $3.37^{* *}$ & $-.209^{* *}$ & $-.199^{* *}$ \\
Knowledge Beneficial & $0-2$ & $.21(.47)$ & $.27(.51)$ & 198 & .87 & -.062 & -.074 \\
$\begin{array}{l}\text { Aware of alternatives to } \\
\text { control pests }\end{array}$ & $0-3$ & $.68(.94)$ & $.95(1.12)$ & 198 & 1.86 & -.131 & -.110 \\
$\begin{array}{l}\text { Negatives from pesticide } \\
\text { use }\end{array}$ & $0-3$ & $.88(0.79)$ & $1.50(1.05)$ & 198 & $4.69^{* *}$ & $-.313^{* *}$ & $-.272^{* *}$ \\
Define IPM & $0-2$ & $.34(.58)$ & $.29(.54)$ & 198 & .56 & -.096 & -.086 \\
\hline
\end{tabular}

Note. Values in parentheses are standard deviations.

$* p<.05 ; * * p<.01$

Knowledge of Crop Specific Pest Management: A set of knowledge questions for each of the project's priority crops were included in the survey. Since pest and disease identification was an early activity of the IPM CRSP some questions pertained to enlarged photos of specific pests, diseases, or plant damage. Other questions asked for specific responses about resistant varieties, post-harvest storage techniques, disease vectors, or control practices. Responses to these questions were combined to form an index of pest management questions for each crop, and a t-test used to compare means between male and female respondents (Table 12). Significant differences in crop specific pest management knowledge were recorded for beans, groundnuts in Iganga and Kumi and cowpea. Males had more knowledge of pest management knowledge for beans: women had more knowledge of pest management knowledge for groundnuts in both districts and cowpea. Males had more knowledge of pest management knowledge for maize and women had more knowledge for sorghum but there was no significant difference.

Table 12

Mean Differences between Males and Females on Crop Specific Management Knowledge Scale (nonprogram participants only)

\begin{tabular}{|c|c|c|c|c|c|c|}
\hline Variable Name & Range & Gender & $\mathrm{N}$ & $M$ & $d f$ & $t$ \\
\hline \multirow[t]{2}{*}{ Maize (Iganga) } & $0-5$ & Male & 33 & 1.42 & 64 & -1.72 \\
\hline & & Female & 33 & .94 & & \\
\hline \multirow[t]{2}{*}{ Beans (Iganga) } & $0-4$ & Male & 31 & .68 & 62 & $-3.45 * *$ \\
\hline & & Female & 33 & .15 & & \\
\hline \multirow[t]{2}{*}{ Gnuts (Iganga) } & $0-5$ & Male & 17 & .94 & 47 & $3.92 * *$ \\
\hline & & Female & 32 & 1.97 & & \\
\hline \multirow[t]{2}{*}{ Gnuts (Kumi) } & $0-5$ & Male & 39 & 1.97 & 74 & $2.80 * *$ \\
\hline & & Female & 37 & 2.89 & & \\
\hline \multirow{2}{*}{ Sorghum (Kumi) } & $0-6$ & Male & 39 & 3.15 & 74 & .888 \\
\hline & & Female & 37 & 3.37 & & \\
\hline \multirow[t]{2}{*}{ Cowpea (Kumi) } & $0-6$ & Male & 38 & 2.84 & 72 & $2.69 * *$ \\
\hline & & Female & 36 & 3.66 & & \\
\hline
\end{tabular}

Note. Values in parentheses are standard deviations.

$* p<.05 ; * * p<.01$ 


\section{Implications}

The perceptual picture provided by male and female farmers in Eastern Uganda of intrahousehold production relationships is both nuanced and complex. The results of this survey indicate that women played an important role in agricultural production and pest management. However, disaggregating the data by examining other variables such as location or cropping system, and particularly ascertaining the woman's status within the household was important to obtaining a clearer picture of the local context.

The evidence provided in this study indicates that female headed households was a distinctive sub-set of rural production units in terms of their perceptions of on-farm division of labor, decision making, and production knowledge. Family units with both spouses present were more likely to share labor and decision making, whereas women will more likely assume these same responsibilities in de jure and de facto female headed households. These findings concur with others who have found considerable diversity in Sub-Saharan Africa regarding women's role in crop production (Von Braun and Webb, 1989). However, this study provided little evidence to support the assertion made by Malena (1994) that women play a predominant role in pest management. Pest management decisions appear to be made by the household head, whether that person was male or female. Women's knowledge of pests and crop specific management knowledge did not appear to greatly differ from the knowledge of men. Women's local knowledge of pesticide hazards may explain why men are responsible for pesticide purchases and application. Thus strategies that would advocate a primary focus on women would appear to not be justified. Further, the results here strongly suggest that it is not possible to generalize about decisionmaking among food producers for a whole continent. Even within the limited geographic scope of this study, the pattern of decisionmaking and decision-sharing among men and women varied enough between Iganga and Kumi districts that extension programs would have to be accordingly modified.

Women have greater knowledge of dimensional attributes of IPM, particularly awareness of potential harmful effects of synthetic pesticides. On the surface, this does not appear to justify focusing IPM efforts on women. However, if a priori knowledge of IPM indicates awareness of a need, and this awareness is linked to adoption of IPM practices then a case could be made for targeting those with knowledge of IPM, which in this case are women, to expedite adoption of IPM. Sources of information on pesticide usage also vary by gender with men appearing to have greater access than women to alternative and exogenous sources of information. These knowledge differences between men and women need to be recognized and built into extension programs on pesticide use and safety.

The increasing number of female headed households in Sub-Saharan Africa represents an important shift in production relations (Moser, 1993). The main implication of this study is that gender based knowledge and perceptual differences need to be assessed and incorporated into agricultural research and extension program delivery if these programs are to have meaningful and sustainable impacts.

\section{References}

Blumberg, R. L. (1992). African women in agriculture: Farmers, students, extension agents, chiefs. Development Studies Paper Series, Winrock International Institute for Agricultural Development, Morrilton, Arkansas.

Gladwin, C. H., Buher, K. L., Goldman, A., Hiebsch, C., Hildebrand, P., Kidder, G., Langham, M., Lee, D., Nkedi-Kizza, P., \& Williams, D. (1997). Gender and soil fertility in Africa, Chapter 9, In Replenishing soil fertility in Africa: Special publication No. 51, Soil Science Society of America, Madison, Wisconsin.

Malena, C. (1994). Gender issues in integrated pest management in African agriculture. NRI Socio-economic Series 5. Chatham, United Kingdom: Natural Resources Institute.

Moser, Caroline (1993). Gender planning and development. Routledge Publishing. London

Saito, K., Mekonnen, H., \& Spurling, D. (1994). Raising the productivity of women farmers in sub-Saharan Africa. World Bank Discussion Paper: 230. Washington, D.C., The World Bank. 
Snyder, M (1990). Women: The key to ending hunger. The Hunger Project Papers, No.8., The Global Hunger Project.

Staudt, K. (1987). Uncaptured or unmotivated? Women and the Food Crisis in Africa. Rural Sociology 52(1), pp. 37-55.

Tefft, J., Weber, M., \& Staatz, J. (1990). Research methods in the MSU food security in Africa Project: Conceptualizing and implementing policy relevant studies. MSU International Development Papers: Working Paper No. 38. Department of Agricultural Economics, Michigan State University, East Lansing, Michigan.
Von Braun, J., \& Webb, P.J.R. (1989). The Impact of New Crop Technology on the Agricultural Division of Labor. In a West African Setting. Economic Development and Cultural Change, 37(3). The University of Chicago. 